\title{
Searching of Protein Targets for Alpha Lipoic Acid
}

\author{
Wilson Maldonado-Rojas, Jesus Olivero-Verbel* and Carlos Ortega-Zuñiga \\ Environmental and Computational Chemistry Group, Faculty of Pharmaceutical Sciences, \\ University of Cartagena, Campus of Zaragocilla. Cartagena, Colombia
}

Ácido alfa lipóico (ALA) é um dos oxidantes mais poderosos e um cofactor em complexos enzimáticos, apesar de seus mecanismos ainda não serem conhecidos. A pesquisa por alvos proteicos de ALA é fundamental para compreender seus processos de sinalização. Uma abordagem bioinformática foi usada a fim de se encontrar alvos hipotéticos para ALA usando o servidor Target Fishing Dock (TarFisDock). Contagens de afinidade para os melhores resultados foram calculadas pelo AutoDock Vina. Alvos relevantes incluíram leucotrieno A4 hidrolase, canal de potássio voltagem-dependente, alfa-hidroxiesteróide desidrogenase, epóxido hidrolase, proteínas estas envolvidas no câncer, diabetes, desordens neurológica e cardiovascular. As energias de interação corrigidas segundo padrão conterpoise foram calculadas para proteínas que ligam $R$-ALA, e mostraram interações $R$-ALA-resíduos favoráveis. A sobreposição de $R$-ALA com inibidores conhecidos daquelas proteínas, permitu concluir que $R$-ALA adota diferentes conformações espaciais em seus sítios de ligação, podendo ser um inibidor fraco plausível destes alvos e, portanto, este efeito deveria ser considerado quando da realização de estudos sobre seus efeitos bioquímicos.

Alpha lipoic acid (ALA) is one of the most powerful antioxidants and a cofactor in enzyme complexes, although its mechanisms are still unknown. The search for protein targets of ALA is fundamental to understand its signaling pathways. A bioinformatics approach was used to find hypothetical targets for ALA using the Target Fishing Dock Server (TarFisDock). Affinity scores for the best hits were calculated by AutoDock Vina. Relevant targets included leukotriene A4 hydrolase, voltage gated potassium channel, alpha hydroxysteroid dehydrogenase and epoxide hydrolase, proteins involved in cancer, diabetes, and neurological and cardiovascular disorders. The counterpoise-corrected interaction energies calculated for proteins that bind $R$-ALA showed favorable interactions $R$-ALA-residues. Superpositioning of $R$-ALA with known inhibitors of those proteins, together with the finding that $R$-ALA adopts different spatial conformations in their binding sites, suggests $R$-ALA could be a plausible weak inhibitor of these targets, and this effect should be considered when studying its biochemical effects.

Keywords: antioxidant, cofactor, inhibitor, docking, TarFisDock, AutoDock Vina

\section{Introduction}

The alpha lipoic acid (ALA) is a relatively small molecule, a five-carbon carboxylic acid bound to a five-atom cyclic disulfide. It has two enantiomeric configurations ( $R$-ALA and $S$-ALA) and its reduced form is known as dihydrolipoic acid (DHLA) ${ }^{1}$ (Figure 1). ALA was previously considered as a vitamin, but later it was shown to be synthesized by animals and humans, primarily in the liver and kidneys, where it is found at higher concentrations. ${ }^{2,3}$ $R$-ALA naturally occurs in foods, covalently bound to lysine (lipoyllysine), ${ }^{4}$ although quantitative information

*e-mail: joliverov@unicartagena.edu.co
Oxidized form

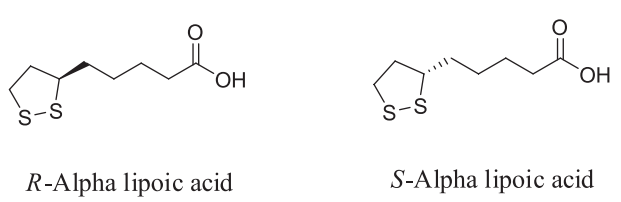

Reduced form<smiles>O=C(O)CCCC[C@H](S)CCS</smiles>

Dihydrolipoic acid

Figure 1. Existing forms of alpha lipoic acid. 
about such adducts is limited. Tissues from animals that are rich in lipoyllysine ( $c a .1 .3 \mu \mathrm{g} \mathrm{g}^{-1}$ dry wt.) include the kidney, heart and liver, while among vegetables, it is found in spinach and broccoli. A small amount of lipoyllysine (ca. $0.5 \mu \mathrm{g} \mathrm{g}^{-1}$ dry wt.) has also been measured in tomatoes, peas and brussels sprouts. ${ }^{5,6}$

ALA is an antioxidant for fatty acids. It is considered an important metabolite for energy production in mitochondria, and it also serves as a potent free radical scavenger in both aqueous and lipophilic media. ${ }^{7-10}$ This compound is used as a drug in many European countries, mainly to treat liver disorders and neuropathies.$^{11}$ Lipoate, or its reduced form, dihydrolipoate, reacts with reactive oxygen species such as superoxide radicals, hydroxyl radicals, hypochlorous acid, peroxyl radicals and singlet oxygen. ${ }^{12,13}$ In general, antioxidant properties of ALA have been related to its capacity to reduce reactive oxygen species (ROS), regenerate endogenous antioxidants, repair oxidative tissue damage and to its chelating capacity. ${ }^{14-16}$

The antioxidant properties of ALA vary depending on the species: the oxidized form is antioxidant, chelating agent for $\mathrm{Fe}$ and $\mathrm{Cu}$, and it can remove ROS. Its reduced form is antioxidant and a Cd-chelating drug. It can also remove ROS, regenerate vitamins $\mathrm{C}, \mathrm{E}$ and glutathione; and increase levels of proteins involved in repair $\left(\alpha\right.$-1-antiprotease). ${ }^{14}$ Dihydrolipoic acid (DHLA) can increase the activity of antioxidants in both aqueous and hydrophobic membrane phases..$^{17-19}$

In vitro experiments have demonstrated that ALA increases glucose uptake by promoting translocation of the glucose transporter GLUT4 to the cell membrane, and this property has been used during alleviation of diseases such as diabetes. ${ }^{20-22}$ The biochemical importance of ALA is mainly represented by its participation as a cofactor in several biological processes, and due to its antiapoptotic action via activation of the insulin receptor/PI3-kinase/Akt pathway. ${ }^{23}$

Nowadays, in silico screening has made possible to find suitable biological targets for particular compounds. Target Fishing Dock (TarFisDock) is a web server that docks small molecules with protein structures in the Potential Drug Target Database (PDTD), as a tool to discover new drug targets. It works performing reverse molecular docking. This process allows docking a particular compound into known binding pockets of proteins found in the PDTD. This server has been used to predict protein binding sites for chemicals such as vitamin $\mathrm{E}$ and $4 \mathrm{H}$-tamoxifen. Experimental evidence has shown that nearly $50 \%$ of the predicted proteins can in fact bind these compounds, indicating the reliability of this server tool. ${ }^{24}$ This tool has been used to identify molecular targets for developing new drugs against Helicobacter pylori, and also as a complementary approach of functional genomics. ${ }^{25} \mathrm{In}$ another study, Olivero et al. ${ }^{26}$ have used TarFisDock to find possible target proteins for TCDD, in particular those related to $\mathrm{Ah} R$-independent activities of TCDD. However, in addition to TarFisDock, there are other available approaches to perform multiple target identification. ${ }^{27}$

In this paper, TarFisDock server has been used to perform virtual screening of molecular targets for ALA, with proper validation of this prediction with different methods of computational chemistry, discussing the possible role of this compound in diseases for which these proteins are important.

\section{Experimental}

\section{Molecular modeling}

For the present study $R$-ALA, $S$-ALA and DHLA structures were optimized using density functional theory (DFT) at the B3LYP/6-31G level. Calculations were carried out with Gaussian 03 package program. ${ }^{28}$ The resultant geometry was translated to Mol2 format with Open Babel $^{29}$ and the optimized ALA structures were submitted to TarFisDock ${ }^{24}$ to find proteins with tri-dimensional structures having theoretical binding sites for each one of the studied species. The search started using the "targets in all categories" option, and ligand docking was performed on all proteins (1207 proteins currently available) present in PDTD. The output consisted of the best hits ranked by an energy score, providing binding conformations and a table with related target information.

\section{Docking validation}

As AutoDock Vina can detect protein cavities for ligand binding on any given protein, it was used to find cavities on randomly selected proteins taken from Protein Data Bank..$^{30}$ Randomly selected protein models 1ABI, 1CA2, 1CAI, 1DFR, 1FDH, 1LCT, 1LFH, 1RHG, 2DHF, 2HHM, 2PAB, 2W9I, 2XAI, 3A1F, 3GPD, 3GRG, 3LHM, 4HVP, $4 \mathrm{I} 1 \mathrm{~B}$ and $8 \mathrm{FAB}$ were docked to $R$-ALA using AutoDock Vina, and the output affinities were utilized to determine a theoretical value for non-specific affinities for $R$-ALA.

Docking ALA structures to target proteins predicted by TarFisDock

$R$-ALA, $S$-ALA and DHLA were docked on each one of the target proteins predicted by TarFisDock, after preparing them using Sybyl 8.1 program. ${ }^{31}$ For protein preparation, 
all hydrogens were added using the Biopolymer module of Sybyl package, and inhibitors within the active site, heteroatoms, and all water molecules were removed. Proteins were minimized applying Kollman's all partial atomic charges, Powell's conjugate gradient method with distance-dependent dielectric constant value of 1.0, and a gradient convergence value of $0.001 \mathrm{kcal} \mathrm{mol}^{-1} .^{32}$ Once minimized, the protein is loaded in MGLTools ${ }^{33}$ creating a PDBQT file that contains a protein structure with hydrogens in all polar residues, and it is then used by the docking program AutoDock Vina $1.0^{34}$ to obtain the affinity binding values for a particular ligand. The docking site for ALA structures on protein targets was defined by establishing a cube with the dimensions $24 \times 24 \times 24 \AA$, covering the binding site predicted for TarFisDock with a grid spacing of $0.375 \AA$ centered on the center of mass of the ligand. Ten runs with AutoDock Vina were performed in all cases per each ALA structure, and for each run the best pose was saved. The average affinity for best poses was taken as the final affinity value for a particular complex. Mammal proteins that showed greater affinity scores for ALA were checked with the program LigandScout $2.0^{35}$ to detect those primary interactions prevailing in the protein-ALA complex. LigandScout is a software tool that allows to rapidly and transparently derive 3D chemical feature-based pharmacophores from structural data of macromolecule-ligand complexes. Its algorithms perform a stepwise interpretation of the ligand molecules: planar ring detection, assignment of functional group patterns, determination of the hybridization state, and finally the assignment of Kekulé pattern. ${ }^{36}$

\section{Counterpoise-corrected interaction energy (CP-CIE) calculations}

In order to evaluate the theoretical likeliness of residues present in the protein binding site being interacting with $R$-ALA, CP-CIE calculations were performed. The protein- $R$-ALA complexes for the mammalian proteins selected by TarFisDock were processed by AutoDock Vina. From these complexes, one was randomly selected per target protein, and then minimized using the standard Tripos molecular mechanics (MM) force field of the SYBYL molecular modeling package, following a Powell energy minimization algorithm, applying GasteigerHückel charges and $0.005 \mathrm{kcal} \mathrm{mol}^{-1} \AA^{-1}$ energy gradient convergence criterion. ${ }^{37,38}$ Following this optimization, molecular dynamics (MD) simulations were performed in vacuo using SYBYL 8.1 force field. ${ }^{39}$ The protocol included (i) a $5000 \mathrm{fs}$ period, beginning at 0 to $300 \mathrm{~K}$, as a heating protocol, (ii) a $10000 \mathrm{fs}$ period at $300 \mathrm{~K}$ was employed for equilibration and (iii) $20000 \mathrm{fs}$ at $300 \mathrm{~K}$ were used in the simulations with a time step of $1 \mathrm{fs} .^{40}$

After these simulations were concluded, the affinities of $R$-ALA for the protein in each one of the final complexes obtained under MM and MD protocols were calculated, ${ }^{41}$ and the geometry and affinities of the these complexes were compared to that given by the structure directly obtained from TarFisDock server.

The relative binding contribution of different residues in the binding site, as predicted by LigandScout 2.0, ${ }^{35}$ was evaluated calculating CP-CIE values, ${ }^{42}$ computed from single-point calculations. This was performed on the structures of the protein- $R$-ALA complexes with the best AutoDock Vina-calculated ligand affinities, following the "Boys and Bernardi" method, ${ }^{43}$ according to equation 1:

$\Delta E(\mathrm{AB})^{\mathrm{CP}}=E^{\mathrm{AB}}{ }_{\mathrm{AB}}(\mathrm{AB})-E^{\mathrm{AB}}(\mathrm{A})-E^{\mathrm{AB}}{ }_{\mathrm{B}}(\mathrm{B})$

where, $\Delta E(\mathrm{AB})^{\mathrm{CP}}$ is $\mathrm{CP}-\mathrm{CIE}$, and $E^{\mathrm{AB}}{ }_{\mathrm{AB}}(\mathrm{AB}), E^{\mathrm{AB}}{ }_{\mathrm{A}}(\mathrm{A})$ and $E^{\mathrm{AB}}{ }_{\mathrm{B}}(\mathrm{B})$ are the total energies computed in a balanced basis set $(\mathrm{AB})$ for complex, residue and ligand ( $R$-ALA) systems, ${ }^{44,45}$ respectively, in order to correct the basis set superposition error (BSSE).

Known inhibitors for TarFisDock-predicted $R$-ALAbinding proteins were found in PubChem and DrugBank, and their affinity scores to such molecules were calculated using AutoDock Vina 1.0. The binding site was set specifically at the site proposed by the TarFisDock server. Similar docking parameters and run number employed for ALA structures were also used for the affinity calculations of inhibitors on target proteins. In order to determine if the docking of $R$-ALA on target proteins takes place under the same ligand conformation, a superposition of the $3 \mathrm{D}$ structures of $R$-ALA docked on the binding sites, together with the optimized $R$-ALA structure as a template, was performed using Sybyl 8.1.1, and visualized by Pymol. ${ }^{46}$ For comparison purposes, CP-CIE values for protein- $R$-ALA complexes were compared to those obtained for the leukotriene A4 hydrolase (1HS6) bound to its inhibitor, bestatin, structure that was taken from Protein Data Bank (PDB).

\section{Results and Discussion}

TarFisDock server was used to find target proteins for $R$-ALA, and AutoDock Vina allowed the calculation of affinity scores for ALA-protein complexes. Based on affinity data provided by AutoDock Vina, non-specific binding of $R$-ALA to randomly selected proteins from PDB occurs at absolute affinity values lower than $5.1 \mathrm{kcal} \mathrm{mol}^{-1}$ (Figure 2). Accordingly, from the best 25 hits suggested by the TarFisDock server as $R$-ALA protein targets, affinities for 


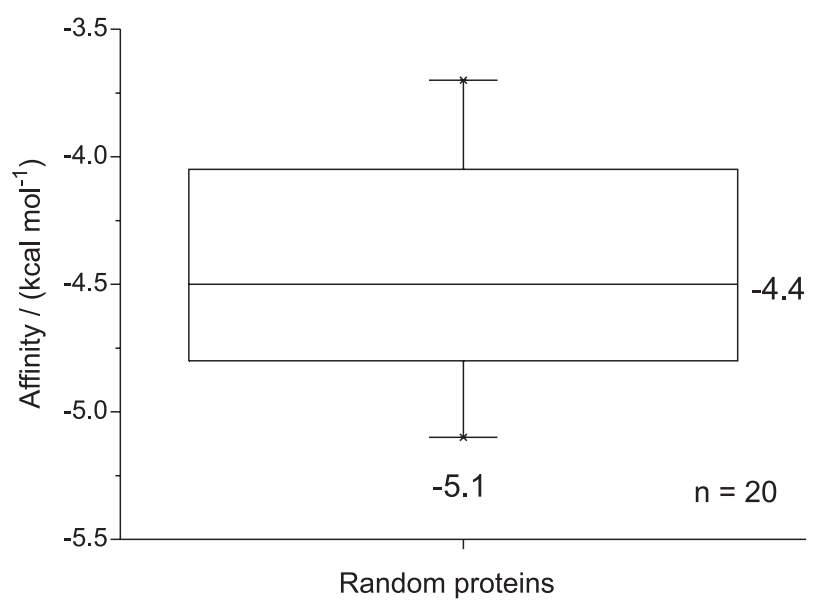

Figure 2. Box-and-whisker diagram showing the affinities of $R$-ALA for twenty randomly selected proteins from PDB.

those with values greater than the maximum $\left(5.1 \mathrm{kcal} \mathrm{mol}^{-1}\right)$ plus its $10 \%(0.5)$, that is $5.6 \mathrm{kcal} \mathrm{mol}^{-1}$, in addition to data obtained for $S$-ALA and DHLA on the same proteins, are shown in Table 1.
Virtual screening of protein targets for ALA showed that, at least hypothetically, this antioxidant could interact with different enzymes such as hydrolases, isomerases, ATPases, oxidases and DNA topoisomerases, among others. In addition, $R$-ALA has indeed similar affinities than $S$-ALA for target proteins, although when the disulfide cycle is broken, as in DHLA, the affinity scores drop significantly (Table 1). Accordingly, it is plausible to think that only the oxidized form of $R$-ALA is more prone to act as a pharmacological agent targeting several proteins.

Some of the proteins predicted to bind ALA are found in mammals (Mus musculus, Homo sapiens, Oryctolagus cuniculus and Bos Taurus) and those represent important pharmacological targets such as leukotriene A4 hydrolase, voltage gated potassium channel, alpha hydroxysteroid dehydrogenase and epoxide hydrolase.

The ligand binding sites for the mammal proteins mentioned before, as well as the interactions between their residues and $R$-ALA in the docking complex, as identified by LigandScout 2.0, are shown in Figure 3. The

Table 1. TarFisDock-predicted proteins that interact with $R$-, $S$-ALA and DHLA

\begin{tabular}{|c|c|c|c|c|c|c|c|}
\hline \multirow[b]{2}{*}{ Protein } & \multirow{2}{*}{$\begin{array}{c}\text { PDB code } \\
\text { (Organism source) }\end{array}$} & \multicolumn{2}{|c|}{$R$-ALA } & \multicolumn{2}{|c|}{$S$-ALA } & \multicolumn{2}{|c|}{ DHLA } \\
\hline & & ES (TFD) & 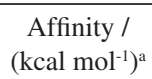 & ES (TFD) & $\begin{array}{c}\text { Affinity / } \\
\left(\mathrm{kcal} \mathrm{mol}^{-1}\right)\end{array}$ & ES (TFD) & $\begin{array}{c}\text { Affinity / } \\
\left(\mathrm{kcal} \mathrm{mol}^{-1}\right)\end{array}$ \\
\hline D-xylose isomerase & $\begin{array}{c}\text { 1DID } \\
\text { (Arthrobacter } s p)\end{array}$ & -30.14 & -5.4 & -27.78 & -5.4 & -29.89 & -4.7 \\
\hline Aldehyde oxidoreductase & $\begin{array}{c}1 \mathrm{VLB} \\
\text { (Desulfovibrio gigas) }\end{array}$ & -29.40 & -6.2 & -28.06 & -6.2 & -28.43 & -5.5 \\
\hline Tryptophan synthase alpha chain & $\begin{array}{c}1 \mathrm{~K} 3 \mathrm{U} \\
\text { (Salm. typhimurium) }\end{array}$ & -27.68 & -6.2 & - & - & -28.61 & -5.4 \\
\hline Epoxide hydrolase & $\begin{array}{c}\text { 1CQZ } \\
\text { (Mus musculus) }\end{array}$ & -27.03 & -6.1 & -25.25 & -6.1 & - & - \\
\hline Leukotriene A4 hydrolase & $\begin{array}{c}1 \mathrm{HS} 6 \\
\text { (Homo sapiens) }\end{array}$ & -26.86 & -6.6 & -26.28 & -6.7 & -27.13 & -5.8 \\
\hline DNA topoisomerase II & $\begin{array}{c}1 \mathrm{PVG} \\
\text { (Sacch. cerevisiae) }\end{array}$ & -26.44 & -5.7 & - & - & - & - \\
\hline $\begin{array}{l}\text { Fab fragment of monoclonal } \\
\text { antibody Db3 }\end{array}$ & $\begin{array}{c}\text { 1DBM } \\
\text { (Mus musculus) }\end{array}$ & -25.96 & -6.1 & -26.56 & -5.9 & -26.37 & -5.3 \\
\hline Voltage gated potassium channel & $\begin{array}{c}\text { 1ZSX } \\
\text { (Homo sapiens) }\end{array}$ & -25.66 & -6.5 & - & - & - & - \\
\hline Beta-glucosidase & $\begin{array}{c}1 \mathrm{E} 1 \mathrm{~F} \\
\text { (Zea mays) }\end{array}$ & -25.55 & -6.0 & -25.21 & -6.2 & -26.47 & -5.4 \\
\hline Alpha hydroxysteroid dehydrogenase & $\begin{array}{c}\text { 1Q5M } \\
\text { (Oryct. cuniculus) }\end{array}$ & -25.31 & -6.2 & - & - & -25.96 & -5.6 \\
\hline $\begin{array}{l}\text { Fab fragment of monoclonal } \\
\text { antibody Db3 }\end{array}$ & $\begin{array}{c}\text { 1DBJ } \\
\text { (Mus musculus) }\end{array}$ & -25.23 & -5.6 & - & - & - & - \\
\hline Beta-glucosidase & $\begin{array}{c}1 \mathrm{E} 55 \\
\text { (Zea mays) }\end{array}$ & -25.17 & -6.0 & -26.12 & -6.0 & -26.68 & -5.3 \\
\hline Polyamine oxidase & $\begin{array}{c}1 \mathrm{H} 82 \\
\text { (Zea mays) }\end{array}$ & -25.14 & -6.0 & -27.08 & -6.2 & -27.09 & -5.5 \\
\hline Bovine mitochondrial F1-ATPase & $\begin{array}{c}\text { 1EFR } \\
\text { (Bos Taurus) }\end{array}$ & -25.04 & -5.7 & - & - & - & - \\
\hline
\end{tabular}

${ }^{\mathrm{a}}$ Mean value $(\mathrm{n}=10)$; in all the cases, the standard error of the mean was lower than $0.09 \mathrm{kcal} \mathrm{mol}^{-1}$; ES: energy score; TFD: TarFisDock; -: TFD did not propose this protein as a target for the ligand. 


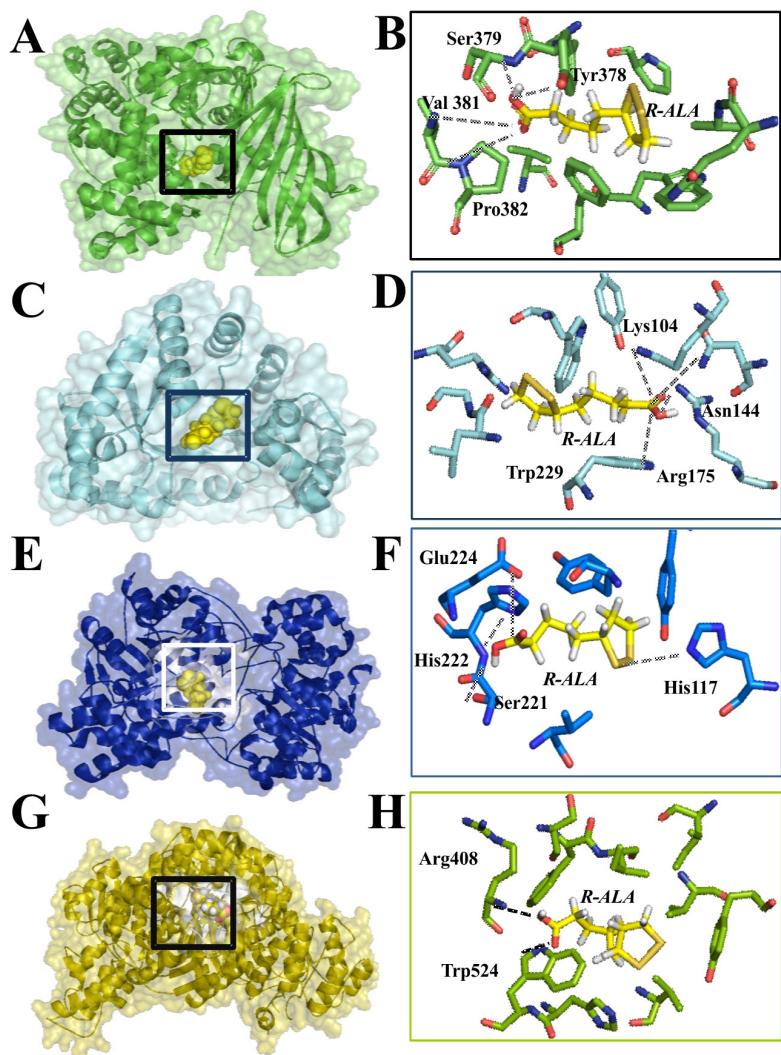

Figure 3. 3D structures of proteins showing the binding sites (left), and main residues involved in the interaction ligand-protein (right) of $R$-ALA to leukotriene A4 hydrolase (A,B), voltage gated potassium channel (C,D), alpha hydroxysteroid dehydrogenase (E,F) and epoxide hydrolase $(\mathrm{G}, \mathrm{H})$, respectively.

ALA-protein binding site for leukotriene A4 hydrolase is determined by Tyr378, Ser379, Val381 and Pro382. For voltage gated potassium channel, these aminoacids are Lys104, Asn144, Arg175 and Trp229, whereas for alpha hydroxysteroid dehydrogenase Glu224, His222, Ser221 and His117. Unlike the previous protein-ligand interactions, this last one occurs with one of the sulfur atoms present in the $R$-ALA. Finally, epoxide hydrolase showed the smaller number of interacting aminoacids in the $R$-ALA binding site, $\operatorname{Arg} 408$ and Trp524.

The AutoDock Vina-calculated affinities of $R$-ALA on target proteins (1HS6, 1ZSX, 1Q5M and 1CQZ) using the structure directly obtained from TarFisDock, the one generated after the optimization by MM, or that resulted from MD simulations of the MM minimized complexes are presented in Table 2. Greater absolute values for affinity binding were obtained for complexes optimized by MM. RMSD values calculated between the 3D structure complexes obtained from TarFisDock and that generated after MM minimization were the lowest, meaning that MM optimization does not dramatically change the 3D structure of the complexes. However, this protocol is important to guarantee better binding affinity scores. Therefore, the MM optimized structure was used to calculate the CP-CIE values between $R$-ALA and all interacting residues, as predicted by LigandScout, and the results are presented in Table 3.

For leukotriene A4 hydrolase (1HS6), all CP-CIE values for binding residues with $R$-ALA were predicted to be negative, suggesting that there is little repulsion between system elements, and therefore a theoretically greater stability in the 1HS6-R-ALA complex formation. ${ }^{23}$ Regarding the other examined proteins (1ZSX, 1Q5M and 1CQZ), not all CP-CIE values were negative, and consequently, the interactions are not totally favorable, although the affinity value calculated for 1ZSX was the same as that obtained for 1HS6.

In order to perform a validation procedure, CP-CIE values were calculated for the 1HS6-bestatin complex, which was available from Protein Data Bank (Table 4). As expected, there is a difference in the number of interacting residues for bestatin (ten), when compared to R-ALA (four). Interestingly, the interacting residue in both cases (TYR378) presented a greater absolute CP-CIE value for bestatin $\left(2.85 \mathrm{kcal} \mathrm{mol}^{-1}\right)$ than for $R$-ALA $\left(0.43 \mathrm{kcal} \mathrm{mol}^{-1}\right)$. However, the interaction between $R$-ALA and SER379 on 1HS6 generated an absolute CP-CIE value of $7.9 \mathrm{kcal} \mathrm{mol}^{-1}$, much greater than those obtained with any residue predicted on the bestatin interaction. This may suggest that $R$-ALA could be acting as a weak inhibitor of 1HS6.

Proteins predicted by TarFisDock to be $R$-ALA targets are key biochemical mediators of several known signaling pathways, for which several inhibitors have been identified. The AutoDock Vina-calculated affinity

Table 2. AutoDock Vina-calculated affinities and RMSD values for protein- $R$-ALA complexes obtained from different methods

\begin{tabular}{|c|c|c|c|c|c|}
\hline Protein & $\begin{array}{l}\text { Affinity / }\left(\mathrm{kcal} \mathrm{mol}^{-1}\right) \\
\text { TarFisDock complex }\end{array}$ & $\begin{array}{l}\text { Affinity / }\left(\mathrm{kcal} \mathrm{mol}^{-1}\right) \\
\text { MM complex }\end{array}$ & $\begin{array}{c}\text { RMSD } \\
\text { TFD vs. MM }\end{array}$ & $\begin{array}{l}\text { Affinity / }\left(\mathrm{kcal} \mathrm{mol}^{-1}\right) \\
\text { MD complex }\end{array}$ & $\begin{array}{c}\text { RMSD } \\
\text { TFD vs. MD }\end{array}$ \\
\hline 1HS6 & -6.6 & -6.7 & 0.230 & -6.3 & 1.447 \\
\hline 1ZSX & -6.5 & -6.7 & 0.193 & -6.5 & 1.539 \\
\hline 1Q5M & -6.2 & -6.2 & 0.105 & -5.5 & 1.879 \\
\hline $1 \mathrm{CQZ}$ & -6.1 & -6.1 & 0.204 & -5.7 & 1.603 \\
\hline
\end{tabular}

MM: molecular mechanics; MD: molecular dynamics. 
Table 3. Counterpoise-corrected interaction energies (CP-CIE) between various residues in protein- $R$-ALA complex ${ }^{a}$

\begin{tabular}{|c|c|c|c|c|c|}
\hline Protein & Residue & Complex energy (Eh) & Residue energy (Eh) & $R$-ALA energy (Eh) & $\mathrm{CP}-\mathrm{CIE} /\left(\mathrm{kcal} \mathrm{mol}^{-1}\right)$ \\
\hline \multirow{4}{*}{ 1HS6 } & TYR378 & -1886.07 & -628.34 & -1257.73 & -0.43 \\
\hline & SER379 & -1655.71 & -397.97 & -1257.73 & -7.15 \\
\hline & VAL381 & -1658.99 & -401.26 & -1257.73 & -0.27 \\
\hline & PRO382 & -1657.81 & -400.08 & -1257.73 & -0.87 \\
\hline \multirow{4}{*}{$1 \mathrm{ZSX}$} & LYS104 & -1753.35 & -495.64 & -1257.71 & -0.80 \\
\hline & ASN144 & -1748.94 & -491.22 & -1257.71 & -3.18 \\
\hline & ARG175 & -1862.60 & -604.89 & -1257.71 & 1.37 \\
\hline & TRP229 & -1942.22 & -684.50 & -1257.71 & -5.51 \\
\hline \multirow{4}{*}{$1 \mathrm{Q} 5 \mathrm{M}$} & HIS117 & -1804.99 & -547.31 & -1257.68 & -0.06 \\
\hline & SER221 & -1655.62 & -397.95 & -1257.68 & 4.13 \\
\hline & HIS222 & -1805.01 & -547.32 & -1257.68 & -6.97 \\
\hline & GLU224 & -1807.89 & -550.22 & -1257.68 & 2.75 \\
\hline \multirow{2}{*}{$1 \mathrm{CQZ}$} & TRP524 & -1942.24 & -684.50 & -1257.73 & -1.84 \\
\hline & ARG408 & -1862.63 & -604.89 & -1257.73 & 0.43 \\
\hline
\end{tabular}

${ }^{\mathrm{a}}$ All calculations were performed with MP2 at the 6-311+g* level of theory; Eh: Hartree energy.

Table 4. Counterpoise-corrected interaction energies CP-CIE for various residues in site active of 1HS6-Bestatin complex ${ }^{\mathrm{a}}$

\begin{tabular}{|c|c|c|c|c|c|}
\hline Protein & Residue & Complex energy (Eh) & Residue energy (Eh) & $R$-ALA energy (Eh) & $\mathrm{CP}-\mathrm{CIE} /\left(\mathrm{kcal} \mathrm{mol}^{-1}\right)$ \\
\hline \multirow{10}{*}{ 1HS6 } & GLY269 & -1315.36 & -283.62 & -1031.72 & -6.00 \\
\hline & ARG563 & -1636.52 & -604.80 & -1031.72 & 0.81 \\
\hline & HIS295 & -1578.95 & -547.23 & -1031.72 & 2.17 \\
\hline & HIS299 & -1578.95 & -547.23 & -1031.72 & 1.70 \\
\hline & TYR378 & -1659.97 & -628.24 & -1031.72 & -2.85 \\
\hline & GLU271 & -1581.95 & -550.22 & -1031.72 & -4.32 \\
\hline & GLU296 & -1581.98 & -550.25 & -1031.72 & -6.10 \\
\hline & GLU318 & -1580.36 & -548.63 & -1031.72 & -3.72 \\
\hline & TYR383 & -1660.07 & -628.34 & -1031.72 & -3.01 \\
\hline & MET270 & -1830.64 & -798.91 & -1031.72 & -3.16 \\
\hline
\end{tabular}

${ }^{\mathrm{a}}$ All calculations were performed with MP2 in 6-311+g* level.

values obtained for some of them are shown in Table 5, and their superposition with $R$-ALA are presented in Figure 4 . With the exception of pergolide, inhibitor of 1ZSX, affinities for these inhibitors were found to be greater than that obtained for $R$-ALA. It is known that bestatin, meclofenamic acid and 1-cyclohexyl-3-decylurea act as ligands in a competitively manner for leukotriene A4 hydroxylase, alpha hydroxysteroid dehydrogenase and epoxide hydrolase, respectively, whereas pergolide works by direct binding on voltage-gated potassium channels. ${ }^{47-51}$ In all these cases, results from AutoDock Vina showed that their binding site is the same predicted

Table 5. AutoDock Vina-calculated affinities for known inhibitors on target proteins

\begin{tabular}{|c|c|c|c|c|}
\hline Protein (PDB-code) & Inhibitor & Affinity / $\left(\mathrm{kcal} \mathrm{mol}^{-1}\right)^{\mathrm{a}}$ & Biological activity & Reference \\
\hline $1 \mathrm{HS} 6$ & bestatin & $-8.5 \pm 0.2$ & $\mathrm{IC}_{50}=4 \mu \mathrm{M}$ & Thunnissen et $a l^{47}$ \\
\hline $1 \mathrm{ZSX}$ & pergolide & $-5.9 \pm 0.1$ & $\mathrm{IC}_{50}=120 \mathrm{nM}$ & Hurs et al. ${ }^{48}$ Hong et al. ${ }^{51}$ \\
\hline 1Q5M & meclofenamic acid & $-8.8 \pm 0.0$ & $\mathrm{~K} i=18.9 \mu \mathrm{M}$ & Haiching et al. ${ }^{49}$ \\
\hline $1 \mathrm{CQZ}$ & 1-cyclohexyl-3-decylurea & $-8.7 \pm 0.0$ & $\mathrm{~K} i=6.3 \pm 0.5 \mathrm{nM}$ & Argiriadi et al. $^{50}$ \\
\hline
\end{tabular}

${ }^{\mathrm{a}}$ Mean value \pm standard error $(\mathrm{n}=10)$; $\mathrm{IC}_{50}$ : half maximal inhibitory concentration; Ki : inhibition constant. 
A<smiles>CC(C)CC(NC(=O)[C@@H](O)[C@H](N)Cc1ccccc1)C(=O)O</smiles>

B Pergolide
(Voltage gated potassium channel)

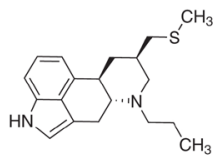

C Meclofenamic acid
(Alpha hydroxysteroid dehydrogenase)<smiles>Cc1ccc(Cl)c(Nc2ccccc2C(=O)O)c1Cl</smiles>

D

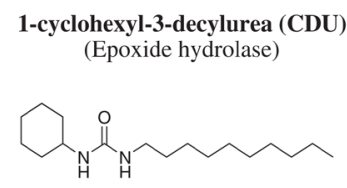

Bestatin

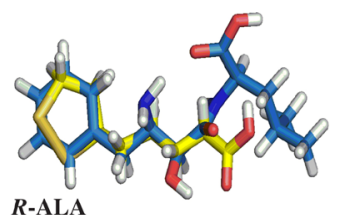

-ALA

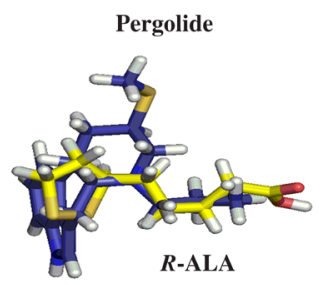

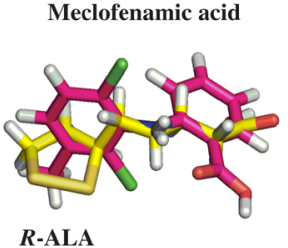

$\boldsymbol{R}$-ALA

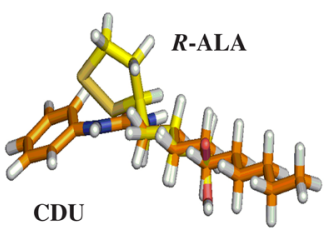

Figure 4. 2D Structure of inhibitors of selected proteins (left) and their 3D-superposition with $R$-ALA (right).

for $R$-ALA. The results of the superposition of different $R$-ALA conformations acquired on binding sites of targets proteins are shown in Figure 5. This analysis shows that $R$-ALA undergoes different spatial conformations when docked on the binding sites of these proteins. This is also

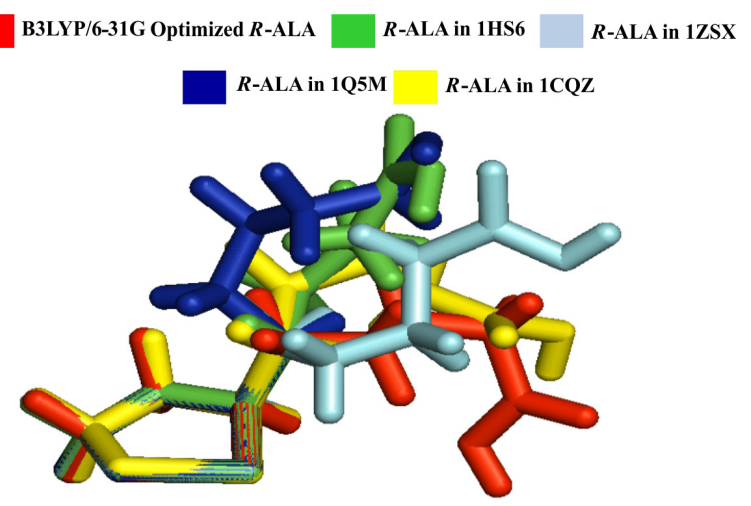

Figure 5. Superposition of the different conformations taken by $R$-ALA in the four target proteins.

in agreement with Figure 3, which shows that $R$-ALA can fit in protein cavities having different types of residue arrangements.

The physiological and toxicological relevance of the interactions between $R$-ALA and predicted targets is still unknown. However, this study unveils the opportunity to open new possibilities for the physiological role of ALA on different biochemical systems in the organisms. The role in human health of those proteins predicted to be $R$-ALA targets by TarFisDock is presented in Table 6 . These data suggest that $R$-ALA can have a wide spectrum of possible biochemical targets within the cell, probably, independently from its major biochemical function as antioxidant. Clearly, these targets are well known for their importance on diabetes, cancer, inflammation and heart disease, among others.

The highest binding affinity for $R$-ALA was obtained for leukotriene A4 hydrolase (LTA4 hydrolase, $\left(-6.6 \mathrm{kcal} \mathrm{mol}^{-1}\right)$ and voltage gated potassium channel $\left(-6.5 \mathrm{kcal} \mathrm{mol}^{-1}\right)$. LTA4 hydrolase specifically acts on ether bonds, and it is

Table 6. Diseases related to the four most important proteins (or their counterparts in humans), predicted to be targets of $R$-ALA

\begin{tabular}{|c|c|c|}
\hline Protein & Related disease & Reference \\
\hline \multirow{3}{*}{$\begin{array}{l}\text { 1HS6 } \\
\text { Leukotriene A4 hydrolase }\end{array}$} & cancer & Chen et al. ${ }^{52,53}$ \\
\hline & psoriasis, cystic fibrosis, asthma and arthritis rheumatoid & $\begin{array}{l}\text { Hicks et al. }{ }^{54} \text { Tager and Luster, }{ }^{55} \text { Iversen et al. }{ }^{56} \text { and } \\
\text { Penning } \text { et al. }{ }^{57}\end{array}$ \\
\hline & cardiovascular disease and inflammation & Funk $^{58}$ \\
\hline \multirow{4}{*}{$\begin{array}{l}\text { 1ZSX } \\
\text { Voltage gated potassium channel }\end{array}$} & diabetes & Yan et al..$^{59}$ \\
\hline & cancer & Teisseyre et al. ${ }^{60}$ \\
\hline & neurological and cardiovascular disorders & Wulff $e t a l .{ }^{61}$ \\
\hline & Parkinson's and Alzheimer's disease & Bednarczyk $^{62}$ \\
\hline \multirow{2}{*}{$\begin{array}{l}\text { 1Q5M }{ }^{\mathrm{a}} \\
\text { Alpha hydroxysteroid dehydrogenase }\end{array}$} & cancer & Lewis et al. ${ }^{63}$ \\
\hline & premature birth & Piekorz et al. ${ }^{64}$ \\
\hline \multirow{2}{*}{$\begin{array}{l}1 \mathrm{CQZ}^{\mathrm{b}} \\
\text { Epoxyde hydrolase }\end{array}$} & diabetes & Oguro et al. ${ }^{65}$ \\
\hline & hypertension and others cardiovascular diseases & $\begin{array}{l}\text { Chiamvimonvat et al. }{ }^{66} \text { Imig and Hammock }{ }^{67} \text { and } \\
\text { Imig et al. }{ }^{68}\end{array}$ \\
\hline
\end{tabular}

${ }^{\mathrm{a}}$ This protein is not present in humans, however its human counterpart 3C3U (AKR1C1), which has about 70\% identity with 1Q5M; bthis protein is not present in humans, but its human counterpart, 3I1Y (soluble epoxide hydrolase), which has about 70\% identity with $1 \mathrm{CQZ}$. 
encoded by the human gene LTA4H ${ }^{69,70}$ It is a bifunctional zinc enzyme (EC: 3.3.2.6) which converts leukotriene A4 to leukotriene $\mathrm{B} 4$, a proinflammatory mediator that has the ability to recruit and activate inflammatory cells, causing tissue damage and disease. ${ }^{71}$ Besides, this leukotriene is as a potent lipid chemoattractant involved in inflammation, immune responses, host defense against infection, platelet activating factor-induced shock, ${ }^{72,73}$ psoriasis, cystic fibrosis, asthma and arthritis rheumatoid, among others. ${ }^{55,62}$ LTA4 hydrolase also acts as aminopeptidase ${ }^{74}$ and it has been linked to esophageal cancer, as its over expression appears to be an early event in this process, therefore being a potential target for the chemoprevention of this disease..$^{52,53}$ Moreover, some authors have linked the presence of this enzyme to the inflammatory component of cardiovascular diseases..$^{58}$

Voltage-gated potassium channels ( $K v$ channels) regulate cellular processes such as the secretion of hormones and repolarization of excitable cells. In pancreatic $\beta$-cells, prolongation of the action potential by blocking of delaying rectifier potassium channels would be expected to increase intracellular free calcium, and to promote insulin release in a glucose-dependent manner, making this protein a potential target for the treatment of type 2 diabetes..$^{59}$ Moreover, alterations in the smooth operation of this transmembrane protein can cause heart diseases, such as arrhythmias. ${ }^{61,75,76}$ Some authors have suggested that inhibition of these potassium channels may exert antiproliferative function in diseases such as of colon, breast and prostate cancer, ${ }^{60}$ as well as benefits in the treatment of Parkinson's and Alzheimer's diseases. ${ }^{62}$

Alpha hydroxysteroid dehydrogenase plays an important role in regulating hormone since it exerts its activity both on androgens (C19 steroids) and progestins (C21 steroids) in rabbits and rats. ${ }^{66,77}$ Its counterpart in humans is AKR1C1, which belongs to the hydroxysteroid dehydrogenase (HSDs) family of enzymes, and plays an important role in the metabolism of progesterone which is essential for the maintenance of pregnancy. This enzyme has been linked to diseases such as cancer ${ }^{63}$ and premature birth. ${ }^{64}$

Epoxide hydrolase is an enzyme that is responsible for the detoxification of mutagenic and carcinogenic agents by the hydrolysis of epoxide substrates. ${ }^{78,79}$ In humans, this enzyme can be deficient in diseases such as diabetes, ${ }^{65}$ although an important role on the metabolism of key inflammatory mediators, like the epoxyeicosatrienoic acids, ${ }^{67}$ and in hypertension have also been reported. ${ }^{66}$ Soluble epoxide hydrolase inhibitors have been considered as potential pharmacologic agents due to their ability to improve vascular function and to reduce renal damage in angiotensin related hypertension. ${ }^{68}$
As presented before, proteins predicted by TarFisDock to be targets for ALA were different from those already known to interact with the antioxidant. This may be explained considering the relatively low number of proteins existing in the PDTD. However, pyruvate dehydrogenase kinase 2 (2BU5), a protein present in the PDTD, known to be inhibited by $R$-alpha lipoic acid, ${ }^{7}$ did not show up as a target. This is consistent with the fact that AutoDock Vina predicted a relatively low binding affinity $\left(-5.8 \pm 0.03 \mathrm{kcal} \mathrm{mol}^{-1}\right)$ of $R$-ALA for this protein.

Finally, one of the most interesting findings in this work was to establish that the 3D-structure of R-ALA can be effectively superimposed to well known inhibitors of target proteins. Although the absolute AutoDock Vina-calculated affinities of these inhibitors for their target proteins are considerably greater than those obtained for $R$-ALA (with the exception of pergolide, inhibitor of 1ZSX). The docking on the binding site, as well as the structural similarities for at least some parts of the inhibitors, suggests that $R$-ALA may be able to enter the ligand binding site of these proteins, probably competing with the endogenous ligands. However, the relative lower affinity bindings recorded for ALA imply that only weak inhibitory or agonist activities may be expected. These computational observations must be validated with experimental evidence, and this will support the findings revealing the pharmacological effect of $R$-ALA on many diseases.

\section{Conclusion}

Virtual screening and docking data suggest that it is plausible that $R$-ALA could behave as a weak inhibitor of proteins such as leukotriene A4 hydrolase and voltage gated potassium channel, characteristics that could explain some of the benefits that have been observed for $R$-ALA on the control and alleviation of diseases on which those have been involved.

\section{Acknowledgements}

The authors wish to thank Colciencias (Bogotá, Colombia) and the University of Cartagena (Cartagena, Colombia) for their financial support (grant 110745921616 , 2009), as well as the program to support research groups, sponsored by the Vice-Rectory for research of the University of Cartagena (2009-2011).

\section{References}

1. Krämer, K.; Hoppe, P.; Packer L. In R-a-Lipoic Acid; Krämer, K.; Packer, L., eds.; Marcel Dekker Inc.: New York, 2001, chapter 9. 
2. Carreau, J. P.; Methods Enzymol. 1979, 62, 152.

3. Ghibu, S.; Richard, C.; Delemasure, S.; Vergely, C.; Mogosana, C.; Muresan A.; Ann. Cardiol. Angeiol. (Paris) 2008, 57, 161.

4. Packer, L.; Hiramatsu, M.; Yoshikawa K.; Antioxidant Food Supplements in Human Health; Academic Press: New York, 1999.

5. Lodge, J. K.; Youn, H. D.; Handelman, G. J.; Konishi, T.; Matsugo, S.; Mathur, W.; Packer, L.; J. Appl. Nutr. 1997, 49, 3.

6. Singh, U.; Jialal I.; Nutr. Rev. 2008, 66, 646.

7. Packer, L.; Cadenas, E.; J. Clin. Biochem. Nutr. 2011, 48, 26.

8. Odabasoglu, F.; Halici, Z.; Aygun, H.; Halici, M.; Atalay, F.; Cakir, A.; Cadirci, E.; Bayir, Y.; Suleyman, H.; Br. J. Nutr. 2011, 105, 31 .

9. Valko, M.; Rhodes, C. J.; Moncol, J.; Izakovic M.; Mazur, M.; Chem. Biol. Interact. 2006, 10, 1.

10. Hassan, B. H.; Cronan, J. E.; J. Biol. Chem. 2011, 286, 8263.

11. Rakel, D. In Dislipidemias; Underbakke, G.; McBride, P. E., eds.; Elsevier: España, 2008, chapter 40.

12. Packer, L.; Witt, E. H.; Tritschler, H. J.; Free Rad. Bio. Med. 1995, 19, 227

13. Bilska, A.; Włodek, L.; Postepy Hig. Med. Dosw. 2002, 56, 201.

14. Biewenga, G. P.; Haenen, G. R. M. N.; Bast, A.; Gen. Pharmacol. 1997, 29, 315.

15. Foo, N. P.; Lin, S. H.; Lee, Y. H.; Wu, M. J.; Wang, Y. J.; Toxicology 2011, 282, 39.

16. Moreira, P. I.; Harris, P. L. R.; Zhu, X.; Santos, M. S.; Oliveira, C. R.; Smith, M. A.; Perry, G.; J. Alzheimers Dis. 2007, 12, 195.

17. Kagan, V. E.; Shvedova, A.; Serbinova, E.; Khan, S.; Swanson, C.; Powell, R.; Packer, L.; Biochem. Pharmacol. 1992, 44, 1637.

18. Çakatay, U.; Med. Hypotheses 2006, 66, 110.

19. Moini, H.; Packer, L.; Saris, N. E. L.; Toxicol. Appl. Pharmacol. 2002, 182, 84.

20. Henriksen, E. J.; Free Rad. Bio. Med. 2006, 40, 3.

21. Packer, L.; Kraemer, K.; Rimbach, G.; Nutrition 2001, 17, 888.

22. Luz, J.; Zemdegs, J. C.; Amaral, L. S.; Diabetes Metab. 2008, 35, 137.

23. Diesel, B.; Kulhanek-Heinze, S.; Holtje, M.; Brandt, B.; Holtje, H. D.; Vollmar, A. M.; Kiemer, A. K.; Biochemistry 2007, 46, 2146.

24. Li, H.; Gao, Z.; Kang, L.; Zhang, H.; Yang, K.; Yu, K.; Luo, X.; Zhu, W.; Chen, K.; Shen, J.; Wang, X.; Jiang, H.; Nucleic Acids Res. 2006, 1, 219.

25. Cai, J.; Han, C.; Hu, T.; Zhang, J.; Wu, D.; Wang, F.; Liu, Y.; Ding, J.; Chen, K.; Yue, J.; Shen, X.; Jiang, H.; Protein Sci. 2006, 15, 2071.

26. Olivero, J.; Cabarcas, M.; Ortega, C.; Chemosphere 2010, 80, 116.

27. Hui-fang, L.; Qing, S.; Jian, Z.; Wei, F.; J. Mol. Graph. Model. 2010, 29, 326.

28. Frisch, M. J.; Trucks, G. W.; Schlegel, H. R.; Scuseria, G. E.; Robb, M. A.; Cheeseman, J. R.; Montgomery Jr., J. A.; Vreven,
T.; Kudin, K. N.; Burant, J. C.; Millam, J. M.; Iyengar, S. S.; Tomasi, J.; Barone, V.; Mennucci, B.; Cossi, M.; Scalmani, G.; Rega, N.; Petersson, G.A.; Nakatsuji, H.; Hada, M.; Ehara, M.; Toyota, K.; Fukuda, R.; Hasegawa, J.; Ishida, M.; Nakajima, T.; Honda, Y.; Kitao, O.; Nakai, H.; Klene, M.; Li, X.; Knox, J. E.; Hratchian, H. P.; Cross, J. B.; Bakken, V.; Adamo, C.; Jaramillo, J.; Gomperts, R.; Stratmann, R. E.; Yazyev, O.; Austin, A. J.; Cammi, R.; Pomelli, C.; Ochterski, J. W.; Ayala, P. Y.; Morokuma, K.; Voth, G. A.; Salvador, P.; Dannenberg, J. J.; Zakrzewski, V. G.; Dapprich, S.; Daniels, A. D.; Strain, M. C.; Farkas, O.; Malick, D. K.; Rabuck, A. D.; Raghavachari, K.; Foresman, J. B.; Ortiz, J. V.; Cui, Q.; Baboul, A. G.; Clifford, S.; Cioslowski, J.; Stefanov, B. B.; Liu, G.; Liashenko, A.; Piskorz, P.; Komaromi, I.; Martin, R. L.; Fox, D. J.; Keith, T.; Al-Laham, M. A.; Peng, C. Y.; Nanayakkara, A.; Challacombe, M.; Gill, P. M. W.; Johnson, B.; Chen, W.; Wong, M. W.; Gonzalez, C.; Pople, J. A.; Gaussian03, Gaussian Inc.: Pittsburgh, 2003.

29. Guha, R.; Howard, M. T.; Hutchison, G. R.; Murray-Rust, P.; Rzepa, H.; Steinbeck, C.; Wegner J. K.; Willighagen, E.; J. Chem. Inf. Model. 2006, 46, 991.

30. http://www.pdb.org/pdb/home/home.do, accessed in November 2010

31. Tripos: A Certera ${ }^{\mathrm{TM}}$ Company, SYBYL Molecular Modeling Software, version 8.1, Tripos Inc.: St. Louis, MO, USA, 2007.

32. Badrinarayan, P.; Sastry, G. N.; J. Chem. Inf. Model. 2011, 51, 115.

33. Sanner, M. F.; J. Mol. Graph. Model. 1999, 17, 57.

34. Trott, O.; Olson, A. J.; J. Comput. Chem. 2009, 31, 455.

35. Wolber, G.; Langer, T.; J. Chem. Inf. Model. 2005, 45, 160.

36. Chen, Z.; Tian, G.; Wang, Z.; Jiang, H.; Shen, J.; Zhu, W.; J. Chem. Inf. Model. 2010, 50, 615.

37. Wlodarczyk, N.; Le Broc-Ryckewaert, D.; Gilleron, P.; Lemoine, A.; Farce, A.; Chavatte, P.; Dubois, J.; Pommery, N.; Hnichart, J. P.; Furman, C.; Millet, R.; J. Med. Chem. 2011, 54, 1178.

38. Kongsaeree, P. T.; Ratananikom, K.; Choengpanya, K.; Tongtubtima, N.; Sujiwattanarat, P.; Porncharoennop, C.; Onpiuma, A.; Svastic, J.; J. Mol. Catal. B: Enzym. 2010, 67, 257.

39. Demutha, C.; Zerbeb, O.; Rognanb, D.; Söllb, R.; BeckSickingerc, A.; Folkersb, G.; Spichiger, U. E.; Biosens. Bioelectron. 2001, 16, 783.

40. Salt, D. W.; Hudson, B. D.; Banting, L.; Ellis, M. J.; Ford. M. G.; J. Med. Chem. 2005, 48, 3214.

41. Suvannang, N.; Nantasenamat, C.; Isarankura-Na-Ayudhya, C.; Prachayasittikul, V.; Molecules (Washington, DC, U. S.) 2011, 16, 3597.

42. Kee, E. A.; Livengood, M. C.; Carter, E. E.; McKenna, M.; Cafiero, M.; J. Phys. Chem. B. 2009, 1139, 14810.

43. Sordo, J. A.; J. Mol. Struct. 2001, 537, 245.

44. Daza, M. C.; Dobado, J. A.; Molina, J.; J. Chem. Phys. 1999, 110, 24. 
45. Dąbkowska, I.; Jurečka, P.; Hobza, P.; J. Chem. Phys. 2005, 122, 204322.

46. DeLano, W.; The PyMol Molecular Graphics System, DeLano Scientific: San Carlos, CA, USA, 2003.

47. Thunnissen, M. M. G. M.; Andersson, B.; Samuelsson, B.; Wong, C. H.; Haeggström, J. Z.; FASEB J. 2002, 16, 1648.

48. Hurst, R. S.; Higdon, N. R.; Lawson, J. A.; Clark, M. A.; Rutherford-Root, K. L.; McDonald, W. G.; Haas, J. V.; McGrath, J. P.; Meglasson, M. D.; Eur. J. Pharmacol. 2003, 482, 31.

49. Haiching, M. A.; Penning, T. M.; Biochem. J. 1999, 341, 853.

50. Argiriadi, M. A.; Morisseau, C.; Goodrow, M. H.; Dowdy, D. L.; Hammock, B. D.; Christianson, D. W.; J. Biol. Chem. 2000, 275, 15265 .

51. Hong, Z.; Smith, A. J.; Archer, S. L.; Wu, X. C.; Nelson, D. P.; Peterson, D.; Johnson, G.; Weir, E. K.; Circulation 2005, 112, 1494.

52. Chen, X.; Li, N.; Wang, S.; Wu, N.; Hong, J.; Jiao, X.; Krasna, M. J.; Beer, D. G.; Yang, C. S.; J. Natl. Cancer Inst. 2003, 95, 1053.

53. Chen, X.; Wang, S.; Wu, N.; Yang, C. S.; Curr. Cancer Drug Targets 2004, 4, 267.

54. Hicks, A.; Monkarsh, S. P.; Hoffman, A. F.; Jr. Goodnow, R.; Exp. Opin. Invest. Drugs 2007, 16, 1909.

55. Tager, A. M.; Luster, A. D.; Prostaglandins, Leukotrienes Essent. Fatty Acids 2003, 69, 123.

56. Iversen, L.; Kragballe, K.; Ziboh, V. A.; Skin Pharmacol. 1997, 10, 169.

57. Penning, T. D.; Russell, M. A.; Chen, B. B; Chen, H. Y.; Liang, C. D.; Mahoney, M. W.; Malecha, J. W.; Miyashiro, J. M.; Yu, S. S.; Askonas, L. J.; Gierse, J. K.; Harding, E. I.; Highkin, M. K.; Kachur, J. F.; Kim, S. H.; Villani-Price, D.; Pyla, E. Y.; Ghoreishi-Haack, N. S.; Smith, W. G.; J. Med. Chem. 2002, 45, 3482.

58. Funk, C. D.; Nat. Rev. Drug Discovery 2005, 4, 664.

59. Yan, L.; Figueroa, D. J.; Austin, C. P.; Liu, Y.; Bugianesi, R. M.; Slaughter, R. S.; Kaczorowski, G. J.; Diabetes 2004, 53, 597.

60. Teisseyre, A.; Duarte, N.; Ferreira, M. J.; Michalak, K.; J. Physiol. Pharmacol. 2009, 60, 69.

61. Wulff, H.; Castle, N. A.; Pardo, L. A.; Nat. Rev. Drug Discovery 2009, 8, 982.
62. Bednarczyk, P.; Acta Biochim. Pol. 2009, 56, 385.

63. Lewis, M. J.; Wiebe, J. P.; Heathcote, J. G.; BMC Cancer 2004, $4,27$.

64. Piekorz, R. P.; Gingras, S.; Hoffmeyer, A.; Ihle, J. N.; Weinstein, Y.; Mol. Endocrinol. 2005, 19, 431.

65. Oguro, A.; Fujita, N.; Imaoka, S.; Drug Metab. Pharmacokinet. 2009, 24, 438.

66. Chiamvimonvat, N.; Ho, C. M.; Tsai, H. J.; Hammock, B.; J. Cardiovasc. Pharmacol. 2007, 50, 225.

67. Imig, J. D.; Hammock, B. D.; Nat. Rev. Drug Discovery 2009 , $8,794$.

68. Imig, J. D.; Carpenter, M. A.; Shaw, S.; Pharmaceuticals 2009, $2,217$.

69. Mancini, J. A., Evans, J. F.; Eur. J. Biochem. 1995, 231, 65.

70. Jiang, X.; Zhou, L.; Wu, Y.; Wei, D.; Sun, C.; Jia, J.; Liu, Y.; Lai, L.; ChemBioChem. 2010, 11, 1120.

71. Haeggstrom. J. Z.; Am. J. Respir. Crit. Care. Med. 2000, 16, 25.

72. Thunnissen, M. M.; Nordlund, P.; Haeggstrom, J. Z.; Nat. Struct. Biol. 2001, 8, 131.

73. Sharma, J. N.; Mohammed, L. A.; Inflammopharmacology 2006 , $14,10$.

74. Rudberg, P. C.; Tholander, F.; Andberg, M.; Thunnissen, M. G.; Haeggström, J. Z.; J. Biol. Chem. 2004, 279, 27376.

75. Wickman, K.; Krapivinsky, G.; Corey, S.; Kennedy, M.; Nemec, J.; Medina, I.; Clapham, D. E.; Ann. N. Y. Acad. Sci. 1999, 868, 386.

76. Schmalhofer, W. A.; Swensen, A. M.; Thomas, B. S.; Felix, J. P.; Haedo, R. J.; Solly, K.; Kiss, L.; Kaczorowski, G. J.; Garcia M. L.; Assay Drug Dev. Technol. 2010, 8, 714.

77. Couture, J. F.; Legrand, P.; Cantin, L.; Labrie, F.; Luu-The, V.; Breton, R.; J. Mol. Biol. 2004, 339, 89.

78. Argiriadi, M. A.; Morisseau, C.; Hammock, B. D.; Christianson, D. W.; Proc. Natl. Acad. Sci. U. S. A. 1999, 96, 10637.

79. Yang, X., Liang, S. H.; Weyant, D. M.; Lazarus, P.; Gallagher, C. J. Omiecinski, C. J.; J. Pharmacol. Exp. Ther. 2009, 330, 23.

Submitted: March 17, 2011

Published online: July 14, 2011 